\title{
THE ASSESSMENT AND DISTRIBUTION OF HEAVY METALS IN SURFACE SEDIMENTS FROM THE RESERVOIR “BARJE” (SERBIA)
}

Zoran B. Todorovićc ${ }^{*}$, Ljiljana M. Ranđelović ${ }^{2}$, Jelena Z. Marjanović1, Vanja M. Todorović ${ }^{3}$, Milorad D. Cakić ${ }^{1}$, Olga G. Cvetkovic ${ }^{4}$

${ }^{1}$ Faculty of Technology, University of Niš, Leskovac, Serbia

2 Water Supply, Public Utility Company, Leskovac, Serbia

${ }^{3}$ Faculty of Pharmacy, University of Belgrade, Belgrade Serbia

${ }^{4}$ Institute of Chemistry, Technology and Metallurgy, Belgrade, Serbia

In this study, the nature of the association of heavy metals ( $\mathrm{Fe}, \mathrm{Co}, \mathrm{Ni}, \mathrm{Cu}, \mathrm{Cd}$, $\mathrm{Pb}, \mathrm{Mn}$, and $\mathrm{Zn}$ ) in sediments of the recent reservoir "Barje" (Leskovac, Serbia) was investigated. The aim was to make the identification of their substrates, as well as to define the external factors (hydrological and anthropogenic affecting their distribution) which will contribute to a better understanding of the interactions that take place in the reservoir and predict the mobility of the investigated heavy metals. Chemical distribution of heavy metals was tested by using the method of sequential extraction and by data processing using statistical methods such as correlation, cluster and factor analysis. Based on the obtained results it can be concluded that major substrates of heavy metals are in the residual immobile fraction ( $\mathrm{Fe}, \mathrm{Zn}$ and $\mathrm{Ni}$ ). Since the accumulation has a small organic substance content, Fe and $\mathrm{Mn}$ oxides are the most important binding substrates of heavy metals. Although it was determined that lead and cadmium are of the carbonate nature, their concentrations in the reservoir are negligible.
(ORIGINAL SCIENTIFIC PAPER) UDC 546.798:627.81

Keywords: heavy metals, sediment, correlation analysis, factor analysis, water reservoir.

\section{Introduction}

During the last decades the heavy metal load, introduced by man, has been equal-to-larger than the natural one. Its occurrence in the environment results primarily from anthropogenic activities, though natural processes that may enrich waters with trace elements also play a noticeable role. A large proportion of heavy metals are dispersed into the air and/or directly into rivers, lakes, sea and reservoirs.

Sediments act both as carriers and potential sources of contaminants in anaquatic environment. Because heavy metals can be either adsorbed onto sediments or accumulated by benthic organisms to toxic level, the bioavailability and subsequent toxicity of the metals are dependent upon various kinds and amounts of the metals bound to the sediment matrices (metal speciation). Sequential extraction results can provide the information on possible chemical forms of heavy metals in sediments. The extraction scheme in the present study is based on operationally defined fractions: exchangeable, carbonate, Mn-oxide, Fe-oxide, organic, and residual. Statistical methods which include the correlation analysis (CA) were used to explore the correlation between various binding fractions of heavy metals and sediment matrices. By using the obtained quantitative correlations, the heavy metal pollution potential can be predicted.

Heavy metals are a special group of contaminants of water reservoirs. Consequently, this zone is an effective sink for most metals naturally as well as anthropogenically introduced to the reservoirs. Temporal variations of metal concentrations show the evidence of the water selfcleaning capacity of the reservoir, despite the high level metal contamination determined [1]. Spatial surveys of heavy metals in sediments are a key step in understanding the contamination in the reservoir systems [2]. The elevation of metal levels in a reservoir is shown mainly by the increase in their concentrations in the bottom sediment. It is well documented that sediments play a key role in the transport and sorption of trace metals in the aquatic environment. The overall behavior of trace metals in the aquatic environment is strongly influenced by the associations of metals with various geochemical phases in sediments [3]. Sediments are complex mixtures of the number of solid phases that may include organic matter, clays, carbonates, silica, metals oxides and other minerals. Consequently, heavy metals can be associated with various operationally defined geochemical phases [4]: (1) adsorbed at particle surfaces, e.g., clays, humic acids, metal oxyhydroxides; (2) bound up with the organic matter in either living or detrital form, and sulphide bound (e.g. amorphous sulphides formed in situ or more crystalline forms); (3) carbonate - bound (e.g. discrete carbonate minerals co-precipitated with major carbonate phases);

\footnotetext{
*Author address: Zoran B. Todorović, Faculty of Technology,

16000 Leskovac, Bulevar Oslobođenja 124, Serbia

e-mail: ztodorovictfle@yahoo.com

The manuscript received: Jun, 27,2014.

Paper accepted: August, 18, 2014.
} 
(4) occluded in iron and/or manganese oxyhydroxides (e.g. discrete nodules, cement between particles, coatings on particles); (5) residual or lithogenic matrix - bound (e.g. bound in lattice positions in aluminosilicates, resistant oxides or sulphides). In order to estimate the distribution of metals among specific geochemical phases, several analytic techniques have been developed $[5,6$, $7,8]$. Although reservoir sediments are characterized by their extreme complexity and diversity, their capacities for associating trace metals can be related to geological parent materials and climatic types in the reservoir basins. The reservoir sediments, especially in the relatively recent, unpolluted river sediments, are the products of rocks and soils within the reservoir basins from continuous weathering and leaching processes [9]. Differences in trace metal concentrations in reservoir sediments of various geographical zones may be attributed to different geological formations and distinct types of weathering processes under diverse geographical conditions. However, relatively little information is available for the geographical variations of sediment bound trace metals in large reservoir systems under different climatic conditions. Contaminants are not necessarily fixed permanently in the sediments. The changes in geochemical parameters (e.g. pH) may cause mobilization of the pollutants. Furthermore, remobilization processes can include the diffusion of pollutants into the water body, because of the concentration gradients, the oxidation of anoxic sediments by bioturbation, or by resuspension caused by flooding. Another remobilization process is the degradation of organic contaminants and a transfer into a more mobile form. The change in the redox potential in sediments is one of the most important factors controlling pollutant mobility. Metal sulfides and organic carbon are oxidized. Both processes enhance the release of sorbed and complexed contaminants [10].

The cluster and factor analysis was performed to simplify the correlations between the metals binding fractions. Clustering is a popular technique used in many different disciplines. It is a series of multivariate methods that is used to find 'true' groups of data, here groups of binding fractions of heavy metals. In clustering, the objects are grouped so that 'similar' objects fall into the same class. The objects in one cluster should be homogenous, with respect to some characteristics describing within cluster properties, and well separated from the elements in other clusters. This separation of clusters is based on some multivariate distance. The dendogram plot shows how far (or close) cases were when they were combined The length of the branch (or link) shows how far apart each case is from other cases in its cluster. The plot rows represent each case on the $Y$ axis and the $X$ axis is rescaled distance coefficients. The cases with low distance have high similarity and are close together. This is usually some variation of the Euclidean distance, based on variable values, on correlation or covariance. There is always a question which clustering procedure is the most suitable. In a review by Sharma [11], the Word's minimum variance technique was superior to most other methods in the sense of giving a larger amount of correct classified observations.

The factor analysis is a technique commonly used to analyze geochemical data. It is a statistical method used for combining a larger number of data into a considerably smaller number of factors. The factors represent groups of the initial mutually linearly dependent parameters and contain the same amount of information as their constituent parameters. The values of coefficients preceding the parameters included in a factor define the significance of a particular parameter for the characterization of the analyzed samples. Variables belonging to a given factor are in high correlation with other variables within that factor, and in low correlation with those belonging to other factors. The analytical process is done statistically first by determining the strongest factor, then removing that factor (statistically) from the data matrix and looking for the next strongest factor. After each step a new factor is removed and the next strongest interrelationship determined. The factor analysis produces a large number of factors. For the purpose of enhancing the coefficients of parameters of high significance within the defined factors, and thus facilitating the interpretation of geological and geochemical data, the so-called varimax rotation is used. Thus the factor analysis results in a matrix of factor loadings. Since variables correlate differently with each other, each variable will correlate differently with the identified factor. Variables will also, generally, show some correlation with other factors [12]. The factor loadings are related to the input provided by individual variables to a given factor and the variables that most strongly load a particular factor can be used to assign the physical meaning of this factor. The statistical data processing was performed by using Statistica for Windows.

The main objective of this study is to investigate metals interrelations in the sediment of the "Barje" reservoir, classify the groups of samples in the sediments and to determine the factors that affect their spatial distribution. Those results are useful in calculating the natural back-ground concentrations of trace metals in reservoir sediments of different regions and for providing baseline levels for the contamination assessment.

\section{Experimental part}

\section{Materials and methods}

Sampling locations are shown in Figure 1. The "Barje" reservoir is located at an altitude of $428 \mathrm{~m}$ above the sea level, covering an area of $10 \mathrm{~km}^{2}$, maximum depth of 50 $\mathrm{m}$ and the reservoir storage capacity of approximately $41 \times 106 \mathrm{~m}^{3}$. The "Barje" reservoiris fed by the Veternica River, $30 \mathrm{~km}$ south of Leskovac (Serbia). This reservoir was built for the protection from flood water, droughts and for supplying Leskovac with drinking water. 


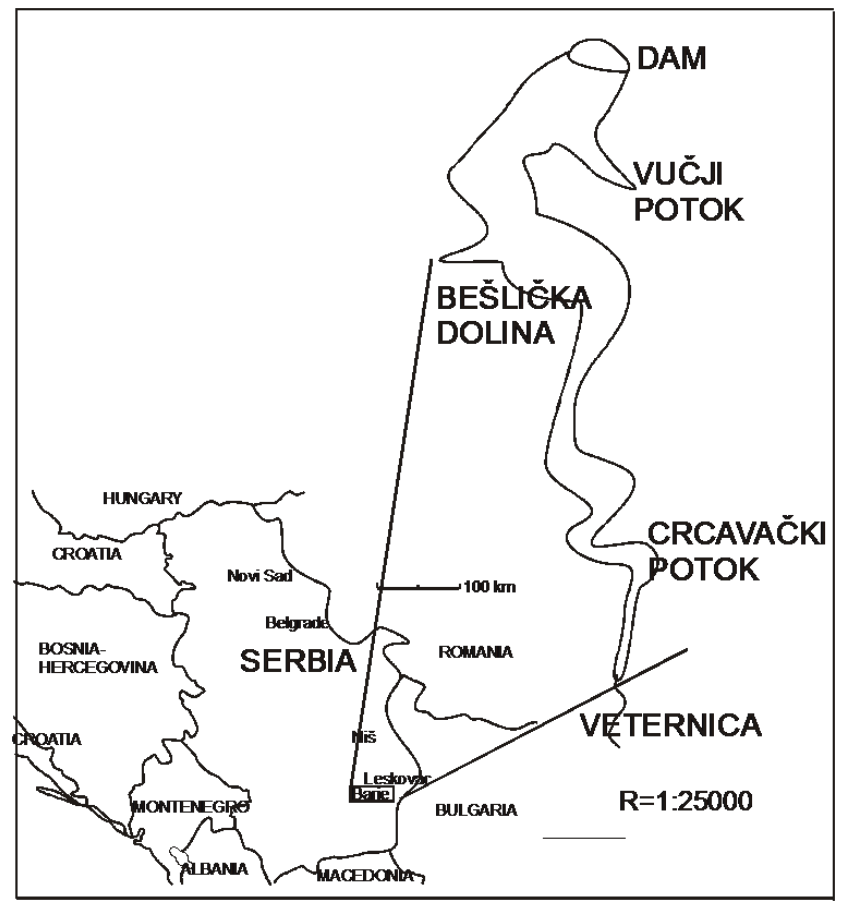

Figure 1.Site map.

Surface sediment samples were taken in February, June, September and December 2012 from six different locations (close to the dam of the accumulation, at the water tower, from the middle of the accumulation and from the tributaries such as: Veternica, Bešlička dolina and Vučji potok). Sediment cores collected at each sampling stations were stored at $4-6{ }^{\circ} \mathrm{C}$ immediately after the collection until the laboratory analysis. In this work a modification of the extraction scheme was used. As recommended by Foerstner et al., [13], in the second phase the selective extraction of carbonates was omitted because of the fact that their destruction causes the dissolution of hydrated oxides, but the point was to separate $\mathrm{Mn}$-oxide fraction from Fe-oxide fraction. Also, instead of total degradation of the residual fraction after the fourth extraction step, a procedure for the degradation of the crystallized iron oxide phase was applied to improve the selectivity of the sequential extraction procedure. Under the conditions applied in the employed extraction procedure (fifth step), most of the crystallized iron oxides present were dissolved. The residual silicate matrix, which remains after the extraction steps, can be considered as highly immobile and insignificant from the point of view of the environmental chemistry.

The following five steps were used in the sequential extraction procedure (with a solid/solution ratio 1:45): Step 1 (S1) - exchangeable metals. The sediment sample was first extracted with $1 \mathrm{M} \mathrm{CH}_{3} \mathrm{COONH}_{4}(\mathrm{pH} 7)$ by shaking for $2 \mathrm{~h}$. Step 2 (S2) - metals bound to carbonates and easily reducible phases (Mn-oxide, partly amorphous Fe oxide). The solid residue from $\mathrm{S} 1$ was first treated with small aliquots $\left(1-2 \mathrm{~cm}^{3}\right)$ of $0.6 \mathrm{M} \mathrm{HCl}$ to maintain $\mathrm{pH} 4$ for the carbonate removal and then ex- tracted with $0.1 \mathrm{M} \mathrm{NH}_{2} \mathrm{OH} \times \mathrm{HCl}$ in $0.01 \mathrm{M} \mathrm{HCl}\left(\mathrm{pH}_{2}\right)$ for $9 \mathrm{~h}$ [14]. Step 3 (S3) - metals bound to moderately reducible phases (more crystalline Mn-oxides and amorphous and poorly crystalline Fe-oxide). The solid residue from S2 was extracted with $0.2 \mathrm{M}\left(\mathrm{NH}_{4}\right)_{2} \mathrm{C}_{2} \mathrm{O}_{4}$ and $0.2 \mathrm{M} \mathrm{H}_{2} \mathrm{C}_{2} \mathrm{O}_{4}$ ( $\mathrm{pH} 3$ ) by shaking for $7 \mathrm{~h}$. Step 4 (S4)-metals bound to organic matter and sulfides. The residue from S3 was extracted at $85 \pm 2{ }^{\circ} \mathrm{C}$ for $5 \mathrm{~h}$ with $30 \% \quad \mathrm{H}_{2} \mathrm{O}_{2}$ (adjusted to $\mathrm{pH} 2$ by addition of $\mathrm{HNO}_{3}$ ), followed by cooling and mixing with $3.2 \mathrm{M} \mathrm{CH}_{3} \mathrm{COONH}_{4}$ by agitating for $30 \mathrm{~min}$. Step 5 (S5)-metal fraction bound to acid soluble residue (detritus silicates, crystalline Fe-oxide). The solid residue from S4 was digested at $85 \pm 2{ }^{\circ} \mathrm{C}$ for $9 \mathrm{~h}$ with $6 \mathrm{M}$ $\mathrm{HCl}$ [15]. Most of crystalline oxides are dissolved by this procedure except for some types of silicate minerals.

The metals were analyzed by the atomic absorption spectroscopy (Spectra A55 Varian spectrophotometer, equipped with a hydride vapor system). All measurements were performed in air/acetylene flame. The wavelengths used in this analysis were: $279.5 \mathrm{~nm}$ for $\mathrm{Mn}$, $372.0 \mathrm{~nm}$ Fe, $232.0 \mathrm{~nm} \mathrm{Ni}, 213.9$ nm Zn, $324.7 \mathrm{~nm} \mathrm{Cu}$ and $217.0 \mathrm{~nm}$ for $\mathrm{Pb}$. External standard solutions were prepared from $1000 \mathrm{mgL}^{-1}$ stock metal solutions. For minimized interferences, we prepared a multi-element standard stock solution in which ratios of metals in this multiple element calibration standards were analogous of their ratio in the samples. These multi-element standard and blanks were prepared in the same matrix as the extracting reagents to minimize matrix effects and for the background correction.

The results of the sequential chemical extraction of the top sediments are summarized in Table 1. 
Table 1. Means and ranges of heavy metal concentrations in various operationally defined geochemical fractions $\left(\mathrm{mg} \mathrm{Kg}^{-1}\right)$.

\begin{tabular}{|c|c|c|c|c|c|c|c|}
\hline & & \multicolumn{2}{|c|}{ Exchangeable } & \multirow{3}{*}{$\begin{array}{l}\text { Carbonate } \\
\text { and } \\
\text { Mn oxide }\end{array}$} & \multirow[t]{3}{*}{ Fe-oxide } & \multirow{3}{*}{$\begin{array}{l}\text { Organic } \\
\text { and } \\
\text { sulphides }\end{array}$} & \multirow[t]{3}{*}{ Residual } \\
\hline & & March & Others & & & & \\
\hline & & & & & & & \\
\hline \multirow[t]{3}{*}{$\mathrm{Fe}$} & Mean & $958 \pm 83$ & $3.7 \pm 0.54$ & $705 \pm 211$ & $1611 \pm 903$ & $16.2 \pm 2.4$ & $2236 \pm 16.5$ \\
\hline & Range & $900-1408$ & $3.10-35.1$ & $204-1456$ & $470-2300$ & $4.9-133$ & $1970-4400$ \\
\hline & $\left(\%^{a}\right)$ & 14.8 & 1.0 & 10.9 & 24.8 & 0.2 & 34.4 \\
\hline \multirow[t]{3}{*}{$\mathrm{Mn}$} & Mean & $285 \pm 28$ & $46 \pm 21$ & $44 \pm 27$ & $17.9 \pm 10.3$ & $3.1 \pm 0.4$ & $27.4 \pm 9.6$ \\
\hline & Range & $265-1220$ & $1.87-54$ & $5.5-424$ & 4.6-133 & $0.35-7.0$ & $1.5-52$ \\
\hline & $\left(\%^{a}\right)$ & 37.7 & 6.2 & 5.8 & 2.4 & 0.4 & 3.6 \\
\hline \multirow[t]{3}{*}{$\mathrm{K}$} & Mean & $407 \pm 95$ & $19.6 \pm 6.8$ & $8.6 \pm 16.1$ & $4.6 \pm 3.2$ & $24.9 \pm 8.5$ & $1241 \pm 46.4$ \\
\hline & Range & $63-3000$ & $2.4-107$ & $3.9-67.8$ & $3.6-49.1$ & $7.05-101$ & $17.9-7940$ \\
\hline & $\left(\%^{a}\right)$ & 19.1 & 0.9 & 0.4 & 0.2 & 1.2 & 58.2 \\
\hline \multirow[t]{3}{*}{$\mathrm{Mg}$} & Mean & $266 \pm 35$ & $89 \pm 19$ & $76 \pm 27$ & $124 \pm 49$ & $208 \pm 123$ & $1499 \pm 527$ \\
\hline & Range & $35-1161$ & $31-638$ & $18-527$ & $76-1251$ & $57-437$ & $804-8962$ \\
\hline & $\left(\%{ }^{a}\right)$ & 10.2 & 3.4 & 2.9 & 4.7 & 8.0 & 57.4 \\
\hline \multirow[t]{3}{*}{$\mathrm{Ni}$} & Mean & $1.53 \pm 0.15$ & $0.14 \pm 0.09$ & $0.72 \pm 0.91$ & $0.99 \pm 0.53$ & $0.62 \pm 0.23$ & $4.55 \pm 0.77$ \\
\hline & Range & $0.15-2.5$ & ND-1.1 & $0.08-5.9$ & ND-10.1 & ND-1.3 & $2.6-7.6$ \\
\hline & $\left(\%^{a}\right)$ & 14.9 & 1.4 & 7.1 & 9.7 & 6.1 & 44.5 \\
\hline \multirow[t]{3}{*}{$\mathrm{Pb}$} & Mean & $2.17 \pm 0.95$ & $0.14 \pm 0.04$ & $1.16 \pm 0.51$ & $0.81 \pm 0.21$ & $0.00 \pm 0.00$ & $0.00 \pm 0.00$ \\
\hline & Range & ND-3.4 & ND-0.8 & $0.08-1.9$ & ND-0.9 & ND & ND \\
\hline & $\left(\%{ }^{a}\right)$ & 27.6 & 1.3 & 14.8 & 27.4 & 0.00 & 0.00 \\
\hline \multirow[t]{3}{*}{$\mathrm{Cd}$} & Mean & $0.00 \pm 0.00$ & $0.00 \pm 0.00$ & $0.02 \pm 0.01$ & $0.00 \pm 0.00$ & $0.00 \pm 0.00$ & $0.00 \pm 0.00$ \\
\hline & Range & ND & ND & ND-0.02 & ND & ND & ND \\
\hline & $\left(\%^{\mathrm{a}}\right)$ & 0.00 & 0.00 & 100.00 & 0.00 & 0.00 & 0.00 \\
\hline \multirow[t]{3}{*}{$\mathrm{Cu}$} & Mean & $0.95 \pm 0.02$ & $0.08 \pm 0.03$ & $0.39 \pm 0.20$ & $4.07 \pm 2.60$ & $0.00 \pm 0.00$ & $3.09 \pm 1.49$ \\
\hline & Range & $0.02-1.0$ & ND-1.1 & $0.10-2.9$ & $1.20-5.6$ & ND & $2.8-5.7$ \\
\hline & $\left(\%^{a}\right)$ & 11.6 & 0.9 & 4.7 & 49.7 & 0.00 & 37.8 \\
\hline \multirow[t]{3}{*}{$\mathrm{Zn}$} & Mean & $1.51 \pm 0.44$ & $0.16 \pm 0.06$ & $1.73 \pm 0.79$ & $4.06 \pm 1.70$ & $0.13 \pm 0.05$ & $12.96 \pm 6.51$ \\
\hline & Range & $0.1-7.3$ & ND-2.6 & $0.48-4.1$ & $3.9-6.7$ & ND-0.7 & $6.6-22.8$ \\
\hline & $\left(\%^{a}\right)$ & 6.8 & 0.7 & 7.8 & 18.3 & 0.6 & 58.3 \\
\hline
\end{tabular}

(ND) not detectable; $\left(\%^{\mathrm{a}}\right)$ Ratio percentage of each fraction to total extractions.

Correlation analysis (CA) was used to determine the correlations between any two binding fractions of heavy metals. This is the most commonly used technique for investigating the relationship between two quantitative variables. The goal of $\mathrm{CA}$ is to quantify the strength of the relationship between the variables. To quantify the strength of the relationship, we can calculate the correlation coefficient $(r)$. Its numerical value ranges from +1.0 to $-1.0 . r>0$ indicates a positive linear relationship, $r<0$ indicates a negative linear relationship while $r=0$ indicates no linear relationship.

\section{Results and discussion}

\section{Zinc}

$\mathrm{Zn}$ dominated in the sediments residual fraction, accounting for over $58.3 \%$ of the total $\mathrm{Zn}$ concentration. Among the non-residual fractions, the moderately reducible phases (more crystalline Mn-oxides and amorphous and poorly crystalline Fe-oxide) fraction was much more important than other fractions in all investigated sediments, which accounted for $18 \%$ of the total $\mathrm{Zn}$. The second in order was carbonates and easily reducible phases (Mnoxide, partly amorphous Fe oxide) which accounted for $8 \%$ of the total $\mathrm{Zn}$. The adsorption at the Fe-Mn oxides had higher stability constants than at the carbonates, but the calcium carbonate was a strong absorbent to form complexes with $\mathrm{Zn}$ as double salts $\left(\mathrm{CaCO}_{3} \cdot \mathrm{ZnCO}_{3}\right)$ in the sediments. The $\mathrm{Zn}$ coprecipitation with the carbonates may become an important chemical form, especially when the hydrous iron oxide and the organic matter are less abundant in the sediment. In "Barje" lake sediments, the percentage of the $\mathrm{Zn}$ bound to the organic and the sulphides fraction was very low $(<0.6 \%$ of total $\mathrm{Zn})$ in those sediments.

\section{Copper}

The sediments from the sites in the middle of the lake 
and at the water tower had higher total Cu concentration than those from the sites where the tributaries flow into "Barje" lake. This is probably due to the sediment focusing. The percentage of $\mathrm{Cu}$ associated with different fractions in the sediments from all sites was in the order: Feoxides $(50 \%)>$ residual $(38 \%)>$ exchangeable $(6.3 \%)$ $>$ Mn-oxides (4.7\%) > organic (not detectable). These results are consistent with the data available in literature [16]. When the content of the organic matter is low, the Fe-Mn oxides might become more significant for binding $\mathrm{Cu}$. In spite of high stability constants of the organic $\mathrm{Cu}$ compounds [17] the association of $\mathrm{Cu}$ with the organic matters appeared to be less pronounced due to low content of the organic matters in these sediments.

Nickel

Nickel was mostly concentrated in the residual fraction, although it was present in the small amount in other fractions. Adamoet al. [18] demonstrated that the Ni often occurs as inclusions within the silicate spheres rather than as separate grains by using the scanning electron microscopy and the energy dispersive X-ray analysis. The $\mathrm{Ni}$ inclusions are protected against decomposition, as well as reagent alteration, and only the dissolution of silicates would ensure their extraction. Our results confirm the hypothesis mentioned above. The percentage of the extracted $\mathrm{Ni}$ was in the following order: the acid soluble residue (detritus silicates, crystalline Fe-oxide) (44.5\%) $>$ moderately reducible phases (more crystalline Mn-oxides and amorphous and poorly crystalline Fe-oxide) (9.7\%) > exchangeable $(8.2 \%)>$ carbonates and the easily reducible phases (Mn-oxide, partly amorphous Fe oxide) $(7.1 \%)>$ the organic matter and sulphides $(6.1 \%)$.

As mentioned before [19], the samples taken in the spring time (March samples) have the exchangeable nickel fractions approximately ten times more than the exchangeable nickel fractions of other samples. Carbonates and the Mn-oxyhydroxide nickel fraction were less in the spring samples than in other samples. Obviously, the spring samples have more mobile nickel fractions than other samples. The third nickel fraction was different for the samples taken from the reservoir in relation to the samples taken from the tributaries inflows. The tributaries inflow samples had the negligible third nickel fraction while the samples taken from the middle of the reservoir and close to the dam had the average nickel contents of about $0.99 \mathrm{ppm}$.

\section{Cadmium}

$\mathrm{Cd}$ and $\mathrm{Pb}$ are more leachable from these sediments than other examined heavy metals. The total extracted cadmium content was extremely minimal, mostly under the detection limit. The average content was $0.023 \mathrm{ppm}$ for the tributaries samples and $0.017 \mathrm{ppm}$ for the reservoir samples. The whole cadmium content was extracted in the second fraction, so we can expect the carbonates and $\mathrm{Mn}$-oxyhydroxide as substrates of $\mathrm{Cd}$. Since cadmium was not found in the exchangeable fraction of the spring samples which partially originated from the dissolution of the amorphous $\mathrm{Mn}$ and Fe-oxyhydroxides, this fact allows the conclusion that the $\mathrm{Cd}$ fraction was bound to the carbonate phases. This hypothesis is in accordance with the literature data [20, 21].

\section{Lead}

Significant amounts of $\mathrm{Pb}$ were extracted in the fractions bound to the moderately reducible phases (more crystalline Mn-oxides and amorphous and poorly crystalline Fe-oxide (27.4\%) and carbonates, and easily reducible phases (Mn-oxide, the partly amorphous Fe oxide) (14.8\%). The exchangeable $\mathrm{Pb}$ was abundant only in the samples taken in the spring time $(27.6 \%)$ and in the other samples it was barely $1.3 \%$. The organic matter or sulphides and the acid soluble residue (detritus silicates, crystalline Fe-oxide) fractions of $\mathrm{Pb}$ were not detectable. This suggests that Pbwas immobilized in the sediments by fixing the reactions involving mostly Fe-Mn oxides which may be the major carriers of $\mathrm{Pb}$ in sediments. This conclusion is in the agreement with the literature data [22].

\section{Correlation analysis}

The binding behavior of the five heavy metals bound to the five sediment phases could also be known by performing the correlation matrix. In order to define the association types of various heavy metals forms, their contents were correlated with the contents of $\mathrm{Mg}$ (as carbonates and clays indicators); $\mathrm{Mn}$ extracted in the second and the third extraction step (representing Mnoxyhydroxides) and $\mathrm{Mn}$ extracted in the fifth extraction step representing crystalline Mn-oxides; Fe extracted in the second and the third extraction steps (representing Fe-oxyhydroxides) and Fe extracted in the fifth extraction step representing crystalline Fe-oxides and $\mathrm{K}$ (indicator of hydrous aluminosilicates).

The most significant Pearson correlation coefficients (r) between the extracted heavy metals and the extracted macroelements and the organic matter are shown in Table 2. The significant Pearson correlation coefficients (r) between any two heavy metals are shown in Table 3. In the correlations, metal concentrations were presented in shorten forms ( $\mathrm{Ni} 2$ means nickel extracted in the second extraction step). 
Table 2. Significant correlation (Pearson) coefficients between heavy metals and macroelements and organic matter $(p<0.05)$.

\begin{tabular}{|c|c|c|c|c|c|c|c|c|c|c|}
\hline & \multicolumn{2}{|c|}{ Carbonates } & \multicolumn{2}{|c|}{$\begin{array}{c}\text { Mn- } \\
\text { oxyhydoxides }\end{array}$} & \multirow{2}{*}{$\begin{array}{c}\begin{array}{c}\text { Mn- } \\
\text { oxides }\end{array} \\
\text { Mn5 }\end{array}$} & \multicolumn{2}{|c|}{$\begin{array}{c}\text { Fe- } \\
\text { oxyhydroxides }\end{array}$} & \multirow{2}{*}{$\begin{array}{c}\begin{array}{c}\text { Fe- } \\
\text { oxides }\end{array} \\
\text { Fe5 }\end{array}$} & \multirow{2}{*}{$\begin{array}{c}\text { Silicates } \\
\text { K5 }\end{array}$} & \multirow{2}{*}{$\begin{array}{c}\text { Organic } \\
\text { and } \\
\text { sulphides } \\
\text { Org.Matt. }^{*}\end{array}$} \\
\hline & Mg2 & Mg4 & Mn2 & Mn3 & & $\mathrm{Fe} 2$ & $\mathrm{Fe} 3$ & & & \\
\hline $\mathrm{Ni} 2$ & 0.78 & 0.83 & & 0.64 & & 0.76 & 0.71 & & & \\
\hline $\mathrm{Ni} 3$ & & 0.76 & & 0.81 & 0.77 & 0.78 & 0.68 & 0.86 & 0.81 & \\
\hline $\mathrm{Ni} 4$ & 0.83 & 0.96 & & 0.77 & & 0.84 & 0.82 & & & 0.75 \\
\hline $\mathrm{Ni} 5$ & & & & 0.93 & 0.71 & 0.81 & 0.93 & 0.71 & 0.75 & \\
\hline Cu2 & & & & & & & & & 0.68 & \\
\hline Cu3 & & 0.94 & & 0.84 & 0.69 & 0.92 & 0.92 & & & \\
\hline Cu5 & & 0.81 & & 0.78 & 0.74 & 0.72 & 0.81 & 0.83 & 0.84 & \\
\hline $\mathrm{Pb} 2$ & & 0.95 & & 0.88 & 0.74 & 0.94 & 0.91 & & & \\
\hline $\mathrm{Pb} 3$ & & 0.86 & & 0.82 & 0.69 & 0.91 & 0.92 & & & \\
\hline $\mathrm{Zn} 2$ & 0.79 & 0.84 & 0.69 & 0.74 & & 0.92 & 0.91 & & & 0.73 \\
\hline $\mathrm{Zn} 3$ & & 0.95 & 0.73 & 0.92 & & 0.97 & 0.92 & & & \\
\hline $\mathrm{Zn} 4$ & & & & & & & & & & 0.73 \\
\hline Zn5 & & & & 0.94 & 0.69 & 0.77 & 0.85 & 0.72 & 0.75 & \\
\hline $\mathrm{Cd} 2$ & 0.88 & 0.85 & & & & 0.91 & 0.92 & & & \\
\hline
\end{tabular}

${ }^{*}$ Org.Matt.= organic substance

Table 3. Significant correlation (Pearson) coefficients between any two heavy-metal binding fractions. $(p<0.05)$.

\begin{tabular}{|c|c|c|c|c|c|c|c|c|c|c|c|c|c|c|c|c|c|c|}
\hline & \multicolumn{4}{|c|}{ Echangeable } & \multicolumn{5}{|c|}{ Carbonate and Mn-oxides } & \multicolumn{4}{|c|}{ Fe-oxides } & \multicolumn{2}{|c|}{$\begin{array}{l}\text { Organic } \\
\text { andsulphides }\end{array}$} & \multicolumn{3}{|c|}{ Residual } \\
\hline $\mathrm{Ni1}$ & $\begin{array}{ll}\mathrm{Ni1} \\
100\end{array}$ & Cu1 & $\mathrm{Pb} 1$ & $\mathrm{Zn1}$ & $\mathrm{Ni} 2$ & Cu2 & $\mathrm{Pb} 2$ & $\mathrm{Zn2}$ & $\mathrm{Cd} 2$ & $\mathrm{Ni3}$ & $\mathrm{Cu} 3$ & $\mathrm{~Pb} 3$ & $\mathrm{Zn} 3$ & $\mathrm{Ni4}$ & $\mathrm{Zn} 4$ & Ni5 & Cu5 & $\mathrm{Zn} 5$ \\
\hline Cu1 & 0.74 & 1.00 & & & & & & & & & & & & & & & & \\
\hline $\mathrm{Pb} 1$ & 0.94 & 0.84 & 1.00 & & & & & & & & & & & & & & & \\
\hline $\mathrm{Zn} 1$ & 0.96 & 0.88 & 0.95 & 1.00 & & & & & & & & & & & & & & \\
\hline $\mathrm{Ni} 2$ & & & & & 1.00 & & & & & & & & & & & & & \\
\hline Cu2 & 0.68 & & & & & 1.00 & & & & & & & & & & & & \\
\hline $\mathrm{Pb} 2$ & & & & & 0.70 & & 1.00 & & & & & & & & & & & \\
\hline $\mathrm{Zn} 2$ & & & & & 0.81 & & 0.81 & 1.00 & & & & & & & & & & \\
\hline $\mathrm{Cd} 2$ & & & & & 0.81 & & 0.82 & 0.87 & 1.00 & & & & & & & & & \\
\hline $\mathrm{Ni3}$ & & & & & & & & & & 1.00 & & & & & & & & \\
\hline Cu3 & & & & & & & & & & 0.75 & 1.00 & & & & & & & \\
\hline $\mathrm{Pb} 3$ & & & & & & & & & & & 0.88 & 1.00 & & & & & & \\
\hline $\mathrm{Zn} 3$ & & & & & & & & & & 0.73 & 0.82 & 0.85 & 1.00 & & & & & \\
\hline $\mathrm{Ni4}$ & & & & & & & & & & & 0.89 & 0.87 & 0.85 & 1.00 & & & & \\
\hline $\mathrm{Zn} 4$ & & & & & & & & & & & & & & & 1.00 & & & \\
\hline $\mathrm{Ni5}$ & & & & & & & & & & 0.84 & 0.82 & 0.84 & 0.85 & 0.86 & & 1.00 & & \\
\hline Cu5 & & & & & & & & & & 0.89 & 0.75 & 0.74 & 0.76 & 0.72 & & 0.97 & 1.00 & \\
\hline Zn5 & & & & & & & & & & 0.74 & 0.67 & 0.66 & 0.86 & 0.73 & & 0.83 & 0.85 & 1.00 \\
\hline
\end{tabular}

In the second extracted phase of $\mathrm{Ni}, \mathrm{Cu}, \mathrm{Pb}, \mathrm{Zn}$ and $\mathrm{Cd}$ several substrates can participate: amorphous iron oxide, silicates, carbonates and hydrated $\mathrm{Mn}$ oxides. As a result of these complex geochemical affinity there are very significant positive correlations between $\mathrm{Ni} 2$, $\mathrm{Cu} 2, \mathrm{~Pb} 2, \mathrm{Zn} 2$ and $\mathrm{Cd} 2$. For example, Cd2 as "purely carbonate substrate" is positively correlated with $\mathrm{Ni} 2$ $(r=0.81, p=0.003$; linear correlation (lin. corr.), with Zn2 ( $r=0.87, p=0.000$; lin. corr.) and Pb2 ( $r=0.82$, $p=0.001$; lin. corr.). In all these correlations, negative trends in the geochemical related subpopulations can be distinguished. Such trends may be an indication of the competitive binding of microelements in carbonate substrate. For example, in Ni2 correlations subpopulation of the tributary samples which have no correlationcan be clearly noticed. The other samples of $\mathrm{Ni} 2$ have a significant correlation with cadmium. Those are a direct establishment that $\mathrm{Ni} 2$ has a carbonate nature except for tributary samples. High significance correlations of $\mathrm{Ni} 2$ and $\mathrm{Fe} 2$ and $\mathrm{Fe} 3$ can be an indication of sorptive interaction with mixing of probably closely incorporated amorphous and surface active hydroxide phases. Positive correlations of $\mathrm{Ni} 2$ with Mg2 and Mg4 suggest that carbonates of these heavy metals were incorporated with amorphous iron hydroxides. Particularly interesting is the correlation of $\mathrm{Pb} 2$ with $\mathrm{Zn} 2$. For both microelements it was assumed that those microelements are associated with carbonate and oxide substrates. Their correlation is composed of several subpopulations that between themselves have negative trends. For the second phase of $\mathrm{Cu}$, it was assumed that silicate substrate dominated. This assumption is confirmed by the absence of Cu2 correlation with other microelements in this extraction phase. When the third phase of nickel was analysed, the two subpopulations were distinguished: the first which originates from the location close to the dam and from the middle of the accumulation which had imposing $\mathrm{Ni} 3$ contents and the second which originates from tributaries locations which had negligible Ni3 contents. Significant correlations Ni3 with $\mathrm{Fe}$ and $\mathrm{Mn}$ fractions prove that mobile nickel fractions are derived from $\mathrm{Mn}$ and $\mathrm{Fe}$ oxyhydroxides substrates. The correlation Ni3 with Pb3 for subpopulation of the tributary sediments has a positive trend and proves a carbonate origin of those elements. As in the second, a very similar nature of the lead and zinc can be noticed in the third extraction phase. Namely, the dominant substrates for both microelements are carbonates and hydrated oxides of manganese and iron. A mutual correlation be- 
tween these two microelements clearly group in several subpopulations that have a negative trend, and as for the second phase, indicate the double competitive binding of lead and zinc carbonate and the oxide substrates. The fourth extraction phase has no cadmium, lead and copper. It means that the amounts of the organically or sulphide bound cadmium, lead and copper are negligibly small, i.e. below the limit of the detection. The fourth extraction phase of zinc is significantly different from other microelements and do not have a correlation with other phases, as macro or microelements. The fifth extraction phase does not have cadmium and lead, thus those demonstrated the extraordinary mobility of these two microelements. On the basis of the previous consideration, the other analysed microelements in the fifth extraction phase were assumed to originate from dissolved silicates. Those were proved by the reciprocial, more or less significant positive correlation between them. A completely homogeneous, highly significant positive correlation between Cu5 and Ni5 clearly indicates the silicate origin of these two elements in this extraction phase. Immobile nickel fraction (Ni5) has a significant positive correlation with potassium that confirms the silicate nature. Most mobile copper amounts were well correlated with $\mathrm{Mn}$ and Fe oxyhydroxides while the immobile copper fraction was derived between crystallized iron oxides and silicates. The quantity of the copper extracted in the fourth phase was negligible in spite of the well-known copper preferences to the organic matrix probably because of minor organic substances in sediments and mainly due to the absence of reduction conditions. Lastly, the fifth extraction phase, which was stable against acidified hydrogen peroxide used in the fourth extraction step showed good correlations with macroelements which represent crystallized silicates and iron oxides (K5, Fe5). Lead, which is generally mobile (extracted in the first three phases) was well correlated with carbonates and oxyhydroxides substrates (significant correlations $\mathrm{Pb} 2$ and $\mathrm{Pb} 3$ with $\mathrm{Mg} 4, \mathrm{Mn} 3, \mathrm{Fe} 2$ and $\mathrm{Fe} 3$ ), thus it was confirmed that lead originated from those substrates. A potential risk of the lead pollution was noted especially in spring time, probable due to high mobility of $\mathrm{Mn}$ and Fe oxyhydroxides at that time. The mobile zinc fraction was significant correlated with carbonates and oxyhydroxides. Additional substrates could be organic substances according to a significant correlation. Organic substances showed significant correlations with zinc. Cadmium, which was extracted only in the second extraction step, was mainly carbonates substrates, but Fe-oxyhydroxides could also be additional substrates in smaller amounts (proved by significant correlations $\mathrm{Cd} 2$ with $\mathrm{Mg} 4, \mathrm{Fe} 2$ and Fe3).

\section{Cluster and factor analysis}

The metals parameters calculated for the thirteen investigated sediment samples (Table 1) were submitted to the factor analysis (a computer program Statistica for Windows Realise 5.0). The factor analysis was expected to define the significance of macroelements (Fe, Mn, K and $\mathrm{Mg}$ ) as markers for predicting the binding behavior of the investigated microelements ( $\mathrm{Ni}, \mathrm{Pb}, \mathrm{Cd}, \mathrm{Cu}$ and $\mathrm{Zn}$ ). The factor observed the first step extraction (exchangeable metals), together with the corresponding variance values representing the percentage of the samples which may be characterized, only on the basis of parameters involved in the factor under consideration. Based on the up-to-date statistical investigations, the results of the factor analysis after varimax rotation were shown to be more suitable for application. According to the principles of the factor analysis only parameters, the loadings of which are higher than $|0.6|$, are valuable for defining a factor.

\section{Step 1 (S1) - exchangeable metals}

Metals contents in the first extraction step where exchangeable and adsorptive metals ions extracted by the ammonium acetate solution. The samples which were taken from the locations of the middle lake (1) and "Kula" (2, close to the dam) in spring time (March) have dissimilar contents from other samples. They contain much more micro and macroelements than other samples. The reason for that deviation could be the increased erosion in the spring time and the muddy appearance which cause high iron hydroxide and manganese hydroxide dissolution. Evidently, after iron, magnesium is the next dominate element in all exchangeable samples especially in the samples taken at the location "Kula" close to the lake dam. As it is well known, magnesium could represent carbonate, organic matter or silicate substrates. Based on the well-known data [23], high magnesium contents could originate from intensively dissolution carbonate substrates by ammonium acetate.

Looking at the microelements contain (Table 1), the first extraction step includes lead and copper only in the samples taken from the tributaries and not from the lake samples, so those elements could originate from the anthropogenic sources.

Factor loading values of the exchangeable metals in factors 1, 2, 3 and 4 are shown in Table 4.

Table 4. Factor Loadings (Varimax normalized) for exchangeable metals.

\begin{tabular}{ccccc}
\hline & Factor 1 & Factor 2 & Factor 3 & Factor 4 \\
\hline $\mathrm{Fe}$ & 0.459 & 0.311 & 0.514 & 0.654 \\
$\mathrm{Mn}$ & 0.803 & 0.249 & 0.276 & 0.453 \\
$\mathrm{~K}$ & 0.301 & 0.164 & 0.927 & 0.147 \\
$\mathrm{Mg}$ & 0.826 & 0.125 & 0.444 & 0.311 \\
$\mathrm{Ni}$ & 0.526 & 0.368 & 0.500 & 0.578 \\
$\mathrm{~Pb}$ & 0.402 & 0.425 & 0.132 & 0.799 \\
$\mathrm{Cu}$ & 0.138 & 0.925 & 0.187 & 0.300 \\
$\mathrm{Zn}$ & 0.475 & 0.570 & 0.183 & 0.642 \\
\hline
\end{tabular}




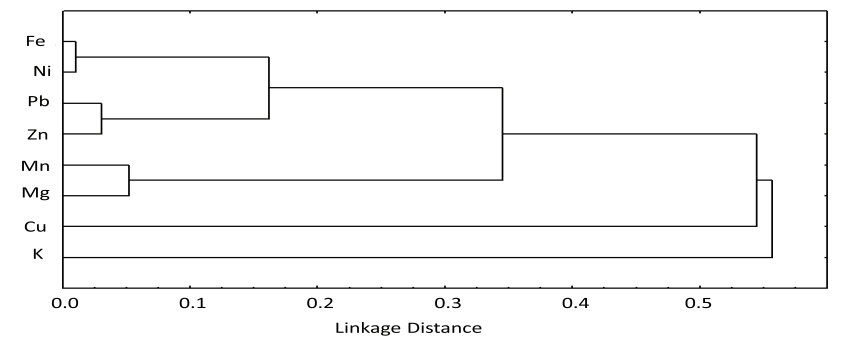

Figure 2.Dendogram tree diagram for exchangeable metals.

Factor 1 (Table 4) has high positive loadings for $\mathrm{Mn}$ and Mg. This similar behavior is shown within the same groups of cluster in dendogram presented in Figure 2. Factor 2 (Table 4) has high positive loadings only for $\mathrm{Cu}$ which suggests a different nature of $\mathrm{Cu}$. The same conclusion can be clearly seen from the dendogram in Figure 2. Potassium, which was adopted to be of a silicate origin is very close to copper, which suggest hat copper is also of a similar origin as potassium. Factor 3 (Table 4) has positive loadings for $\mathrm{Ni}$ and $\mathrm{Fe}$ and suggests a close nature for those metals in the exchangeable fraction. The same conclusion can be clearly seen from the dendogram in Figure 2 where $\mathrm{Fe}$ and $\mathrm{Ni}$ are firstly connected. $\mathrm{Pb}$ and $\mathrm{Zn}$ are firstly connected in the dendogram presented in Figure 2. Also, those metals have a high positive factor 4 which suggests their close correlation and similar nature. It should be noted that for exchangeable metals the small changes in redox potential or $\mathrm{pH}$ of surrounding water can lead to their mobility.

Step 2 (S2)-metals bound to carbonates and easily reducible phases (Mn-oxide, partly amorphous Fe oxide)

Comparing mutually the contents of all extracted elements in the second extraction step (Table 1) it is obvious that iron dominated. Analyzing the elements contents at different locations it can be noted that the iron content in the middle of the lake rises from spring to autumn and it was much higher than at other locations. The significant stratification during the summer increase the reduction conditions in the middle of the lake which enhanced the iron mobility and the iron content. The tributaries sediment samples showed lower iron contents than the lake samples. This was because of the reduction conditions at the deeper water level. According to the expectations, the significant dominations of the manganese content were the result of the manganese hydroxides dissolution. In the second extraction step the potassium content was less than in the first extraction step. The tributaries sediment samples had a larger potassium content in relation to the sediment taken from the accumulation samples, which suggest the silicates domination over the other natures. As it is well-known, the second extraction step mostly consists of carbonates, so all microelements measured in it suggest their carbonate nature.

Factor loading values of the metals bound to carbonates and easily reducible phases (Mn-oxide, partly amorphous Fe oxide) in factors 1, 2, 3 and 4 are shown in Table 5.
Table 5. Factor Loadings (Varimax normalized) for metals bound to carbonates and easily reducible phases (Mn-oxide, partly amorphous Fe oxide).

\begin{tabular}{ccccc}
\hline & Factor 1 & Factor 2 & Factor 3 & Factor 4 \\
\hline $\mathrm{Fe}$ & 0.809 & 0.129 & 0.433 & 0.342 \\
$\mathrm{Mn}$ & 0.363 & 0.002 & 0.218 & 0.899 \\
$\mathrm{~K}$ & -0.062 & 0.956 & 0.027 & 0.144 \\
$\mathrm{Mg}$ & 0.177 & -0.198 & 0.944 & 0.040 \\
$\mathrm{Ni}$ & 0.308 & 0.401 & 0.756 & 0.278 \\
$\mathrm{~Pb}$ & 0.900 & 0.239 & 0.227 & 0.193 \\
$\mathrm{Cd}$ & 0.654 & -0.088 & 0.675 & 0.265 \\
$\mathrm{Cu}$ & 0.586 & 0.884 & -0.095 & -0.179 \\
$\mathrm{Zn}$ & 0.586 & 0.016 & 0.684 & 0.302 \\
\hline
\end{tabular}

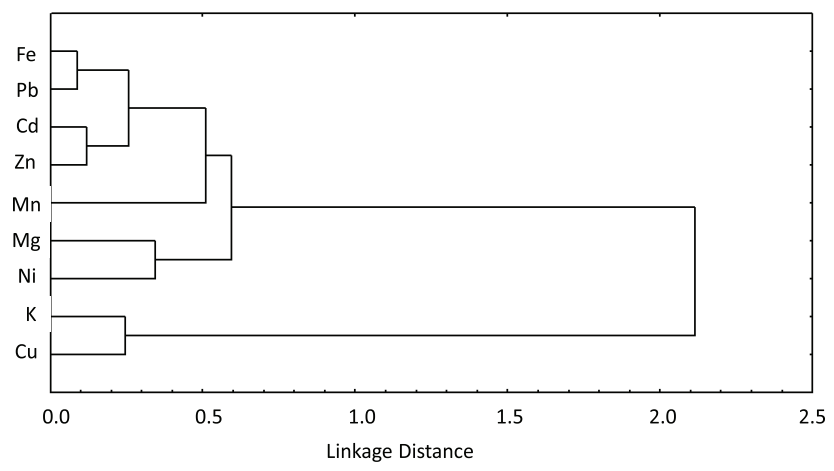

Figure 3. Dendogram tree diagram for metals bound to carbonates and easily reducible phases (Mn-oxide, partly amorphous Fe oxide).

Heavy metals extracted in the second fractions (Table 5 and Figure 3) are separated into three clusters. One is $\mathrm{Cu}$, which is far from other clusters, and very close to the point of potassium extracted indicating that $\mathrm{Cu}$ is probable derived from silicates or the dominant source could be clays. The second are $\mathrm{Pb}, \mathrm{Cd}$ and $\mathrm{Zn}$ which are very close to iron, which suggests that these metals could be abundantly carbonates incorporated into amorphous iron oxyhydroxide. The third is Ni which is close to Mg which can be organic matter or carbonates coprecipitated Mn-oxyhydroxides.

Step 3 (S3) - metals bound to moderately reducible phases (more crystalline Mn-oxides and amorphous and poorly crystalline Fe-oxide)

Factor loading values of the metals bound to carbonates and easily reducible phases (more crystalline $\mathrm{Mn}$ oxides and amorphous and poorly crystalline Fe-oxide) in factors 1, 2, 3 and 4 are shown in Table 6. 
Table 6. Factor Loadings (Varimax normalized) metals bound to moderately reducible phases (amorphous Fe oxide).

\begin{tabular}{ccccc}
\hline & Factor 1 & Factor 2 & Factor 3 & Factor 4 \\
\hline $\mathrm{Fe}$ & 0.707 & 0.453 & 0.461 & 0.272 \\
$\mathrm{Mn}$ & 0.677 & 0.596 & 0.387 & 0.105 \\
$\mathrm{~K}$ & 0.267 & 0.787 & 0.532 & -0.095 \\
$\mathrm{Mg}$ & 0.340 & 0.333 & 0.850 & 0.137 \\
$\mathrm{Ni}$ & 0.328 & 0.890 & 0.165 & 0.244 \\
$\mathrm{~Pb}$ & 0.548 & 0.239 & 0.769 & 0.105 \\
$\mathrm{Cu}$ & 0.613 & 0.354 & 0.510 & 0.467 \\
$\mathrm{Zn}$ & 0.869 & 0.301 & 0.379 & 0.049 \\
\hline
\end{tabular}

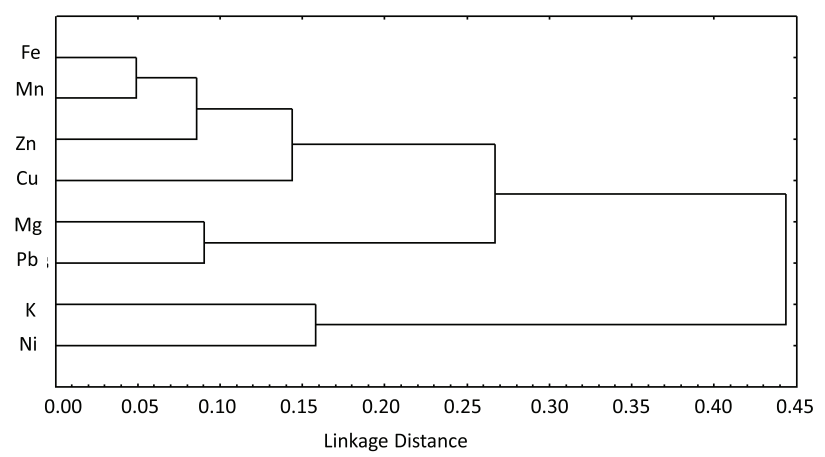

Figure 4. Dendogram tree diagram for metals bound to moderately reducible phases (more crystalline $\mathrm{Mn}$-oxides and amorphous and poorly crystalline Fe-oxide)

The absolute iron domination in the investigated samples in the third extraction step was in accordance with the expectations because it is well-known that oxalate reagent extracts amorphous and poorly crystalline $\mathrm{Fe}$ oxide (Table 1). The two groups of the samples were noticed, one with high magnesium contents (in the middle of the lake and at the Veternica tributary) and the other without magnesium (the samples from the dam). According to the previous assumption that the magnesium originates from carbonates, the samples with its high contents were of the carbonate natures. The third extraction step has potassium only in the sediment samples taken from the inflow tributaries locations, while the samples taken from the accumulation lake have no potassium content. This is in accordance with the attitude concluded from the first extraction step that in the tributaries samples, the silicates dominate over the other natures. Microelements present in all the investigated samples (except cadmium) point out that these metals could mainly have forms incorporated into amorphous iron oxyhydroxide.

If we accept that factor 1 (Table 6) represents $\mathrm{Mn}$ and $\mathrm{Fe}$ oxides, high positive loading values for $\mathrm{Zn}$ and $\mathrm{Cu}$ suggest a close association of these metals with crystalline $\mathrm{Mn}$-oxides and amorphous and poorly crystalline $\mathrm{Fe}$-oxide. Good associations of $\mathrm{Zn}$ and $\mathrm{Cu}$ with $\mathrm{Mn}$ and Fe oxides can be clearly seen from dendogram (Figure 4). Factor 2 has positive loading values for $\mathrm{K}$ and $\mathrm{Ni}$ (Table 6). The same observation can be obtained from dendogram of metals from the third extraction phase (Figure 4). It could represent good associations of $\mathrm{Ni}$ with silicates forms of the samples taken from tributaries. Factor 3 (Table 6) has positive loadings for $\mathrm{Mg}$ and $\mathrm{Pb}$ and suggests their close as- sociations. This similar behavior is shown within the same group of the cluster in dendogram presented in Figure 4. Because Mg could represent carbonate fraction it suggests acarbonate nature of $\mathrm{Pb}$ in the third extraction fraction.

Step 4 (S4)-metals bound to organic matter and sulfides.

Table 7. Factor Loadings (Varimax normalized) metals bound to organic matter and sulphides.

\begin{tabular}{ccccc}
\hline & Factor 1 & Factor 2 & Factor 3 & Factor 4 \\
\hline $\mathrm{Fe}$ & 0.928 & 0.172 & 0.314 & 0.060 \\
$\mathrm{Mn}$ & 0.467 & 0.228 & 0.0851 & 0.010 \\
$\mathrm{~K}$ & 0.855 & -0.021 & 0.500 & -0.115 \\
$\mathrm{Mg}$ & 0.684 & 0.140 & 0.683 & 0.188 \\
$\mathrm{Ni}$ & 0.768 & 0.305 & 0.461 & 0.315 \\
$\mathrm{Zn}$ & 0.107 & 0.983 & 0.139 & 0.030 \\
\hline
\end{tabular}

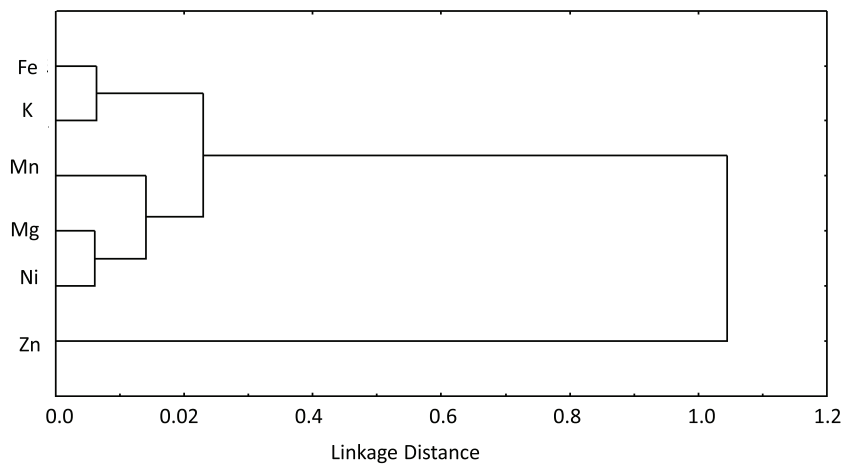

Figure 5. Dendogram tree diagram for metals bound to organic matter and sulphides.

The data of the fourth extraction step provide the following information: generally, magnesium dominates especially in the samples taken from the middle of the lake. It is generally known that carbonates are not completely dissolved with acidified hydroxylamine in the second extraction step because they are captured in the oxide and organic matrix. Magnesium originates from carbonates realized in the third extraction step by the degradation process from amorphous and poorly crystalline Fe-oxide, because oxalate ions are not dissolved until the fourth extraction step. Considering the microelements contents in the fourth extraction phase (Table 1) the absence of cadmium, lead and copper ions is noted, so evidently the organic matteris not significantly associated with those metals and there are not their sulphides in the investigated sediment.

Factor 1 (Table 7) has positive loading values for $\mathrm{Fe}, \mathrm{K}$, $\mathrm{Mg}$, and $\mathrm{Ni}$. Because the hydrogen peroxide can degrade some silicates there are appreciable amounts of potassium, crystalline Fe-oxide and some metals associated with these substrates in the fourth extraction phase. Factor 2 (Table 7) has positive loading values only for $Z n$ which suggests a different $\mathrm{Zn}$ nature in regards to $\mathrm{Fe}, \mathrm{Mn}, \mathrm{K}$ and $\mathrm{Ni}$. This conclusion is confirmed by the dendogram tree diagram for metals bound to organic matter and sulphides (Figure 5). 
Step 5 (S5)- metals fraction bound to the acid soluble residue (detritus silicates, crystalline Fe oxide)

Table 8. Factor Loadings (Varimax normalized) metals fraction bound to the acid soluble residue (detritus silicates, crystalline Fe oxide).

\begin{tabular}{ccccc}
\hline & Factor 1 & Factor 2 & Factor 3 & Factor 4 \\
\hline $\mathrm{Fe}$ & 0.365 & 0.773 & 0.202 & 0.284 \\
$\mathrm{Mn}$ & 0.338 & 0.200 & 0.885 & 0.225 \\
$\mathrm{~K}$ & 0.391 & 0.470 & 0.340 & 0.707 \\
$\mathrm{Mg}$ & 0.544 & 0.479 & 0.470 & 0.493 \\
$\mathrm{Ni}$ & 0.862 & 0.307 & 0.333 & 0.201 \\
$\mathrm{Cu}$ & 0.738 & 0.472 & 0.281 & 0.376 \\
$\mathrm{Zn}$ & 0.657 & 0.281 & 0.330 & 0.307 \\
\hline
\end{tabular}

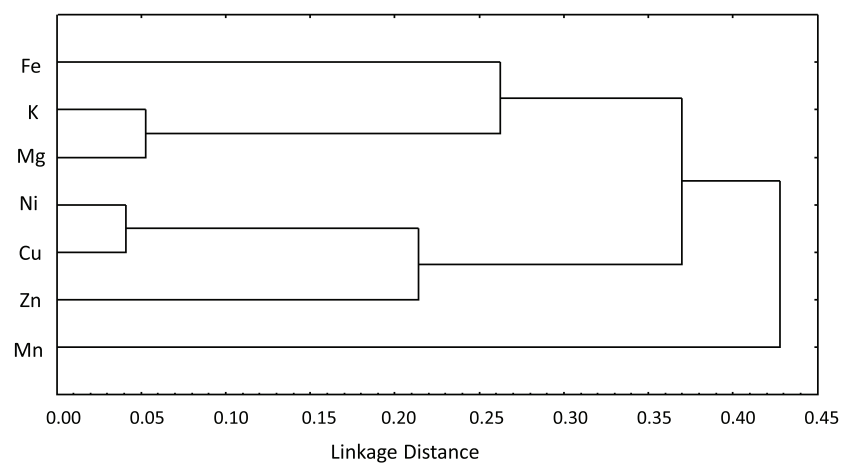

Figure 6. Dendogram tree diagram for metals fraction bound to the acid soluble residue (detritus silicates, crystalline Fe oxide).

In the fifth extraction step, dissolution of crystalline Fe-oxide is partly accompanied by silicates destruction [14]. As it is to be expected, iron is the main constituent (Table 1). The next abundance element is magnesium which can come from carbonates incorporated into iron oxyhydroxide and from dissolved magnesium silicates. Potassium is the next representative element. Its presence significantly represents dissolution of silicates in this extraction phases. Cadmium and lead were absent in this extraction phase, so these elements are not of the silicate nature. By observing other investigated microelements the presence of $\mathrm{Ni}, \mathrm{Cu}$ and $\mathrm{Zn}$ ions was found, so these elements have the silicate nature in the analyzed sediment.

Analyzing the factor loadings in the fifth extraction step for the metals fraction bound to the acid soluble residue (detritus silicates, crystalline Fe oxide) it can be seen that factor 1 (Table 8 ) shows positive loading values for $\mathrm{Ni}$ and $\mathrm{Cu}$, factor 2 shows positive loading values only for $\mathrm{Fe}$, factor 3 shows positive loading values only for $\mathrm{Mn}$ and factor 4 does not show positive loading values. Based on the dendogram tree diagram for the metals fraction bound to the acid soluble residue (detritus silicates, crystalline Fe oxide) presented in Figure 6 it can be concluded that all extracted metals except for $\mathrm{Mn}$ are bound to crystalline Fe-oxide and silicates as expected for the fifth extraction fraction. It is obvious that the fifth extraction phase has crystalline Mn-oxide which is realized by degradation of silicates and crystalline Fe-oxide.

\section{Conclusion}

The present work has been undertaken to establish the chemical partitioning of heavy metals ( $\mathrm{Fe}, \mathrm{Co}, \mathrm{Ni}, \mathrm{Cu}$, $\mathrm{Cd}, \mathrm{Pb}, \mathrm{Mn}$, and $\mathrm{Zn}$ ) contaminations of the recent accumulation "Barje" (Leskovac, Serbia) in order to establish reference data on the reservoir quality and evidence of the water self-cleaning capacity of the reservoir. This study investigated metal interrelations, classified groups of the samples in sediments and defined the factors that affected their spatial distribution. The relative metal bioavailability was evaluated by sequential extraction. This technique allows a better estimation of the contaminant potential of these metals bound to sediments. It was determined that a residual fraction was dominated by $\mathrm{Fe}$, $\mathrm{Zn}$, and Ni distribution in sediments. The sediments in the "Barje" reservoir have low organic matter content. $\mathrm{Fe}-\mathrm{Mn}$ oxides are the most significant binding fractions for $\mathrm{Cu}$ and $\mathrm{Pb}$. Although $\mathrm{Pb}$ and $\mathrm{Cd}$ are easily mobile, their concentrations in the sediment are lower than the natural back-ground concentrations of sediments. Those results are useful in calculating trace metals in the reservoir sediments of different regions and for providing baseline levels for the contamination assessment. The new data will also be important in estimating the global average composition of any sediment in large reservoir systems.

\section{Acknowledgment}

This work has been funded by the Ministry of Education and Science of the Republic of Serbia (Project III 45001)

\section{Literature}

[1] P. Avila-Perez, M. Balcazar, G. Zarazua-Ortega, I. BarceloQuintal, C. Diaz-Delgrado, Heavy metal concentrations in water and bottom sediments of a Mexican reservoir, Science of the Total Environment, 234 (1999) 185-196.

[2] C. Wang, S. Liun, Q. Zhao, L. Deng, S. Dong Spatial variation and contamination assessment of heavy metals in sediments in the Manwan Reservoir, Lancang Riv. Ecotoxicology and Environmental Safety, 82 (2012) 3239.

[3] U. Forstner, G. Wittmann, Metal pollution in the aquatic environment, 2nd ed. Springer, Berlin Heidelberg, New York, 1981, p 37.

[4] A. Tessier, P. G. C. Campbell, Partitioning of trace metals in sediments; Relationships with bioavailability, Hydrobiologia, 149 (1987) 43-52.

[5] A. Tessier, P. G. C. Campbell, M. Bisson, Sequential extraction procedure for the speciation of particulate trace metals, Analytical Chemistry, 51 (1979) 844-851.

[6] G. Rauret, J. F. Lopez-Sanchez, A. Sahuquillo, R. Rubio, C. Davidson, A. Ure, P. Quevauviller, Improvement of the BCR three step sequential extraction procedure prior to the certification of new sediment and soil reference materials, Journal of Environmental Monitoring, 1 (1999) 57-61. 
[7] K. Nemati, N. K. Abu Bakar, M. Radzi Abas, E. Sobhanzadeh, Speciation of heavy metals by modified $\mathrm{BCR}$ sequential extraction procedure in different depths of sediments from Sungai Buloh, Selangor, Malaysia, Journal of Hazardous Materials, 192 (2011) 402-410

[8] M. B. Arain, T. G. Kazi, M. K. Jamali, N. Jalbani, H. I. Afridi, J. A. Baig, Speciation of heavy metals in sediment by conventional, ultrasound and microwave assisted single extraction methods: A comparison with modified sequential extraction procedure, Journal of Hazardous Materials, 154 (2008) 998-1006

[9] J. S. Chen, F. Y. Wang, X. D. Li, J. J. Song, Geographical variations of trace elements in sediments of the major rivers in eastern China, Environmental Geology, 39 (12) (2000) 1334-1340.

[10] T. Zoumis, A. Schmidt, L. Grigorova, W. Calmano, Cantaminants in sediments: remobilisation and demobilisation, Science of the Total Environment, 266 (2001) 195-202.

[11] S. Sharma, Applied Multivariate Techniques, John Wiley and Sons, New York, 1996. p 28.

[12] B. F. J. Manly, Multivariate Statistical Methods, 2nd Edition. Chapman and Hall, New York, 1994.p 93.

[13] U. Foerstner, W. Calmano, K. Conradt, H. Jaksch, C. Schimkus, J. Schoer, Chemical Speciation of heavy metals in solid waste materials (sewage sludge, mining wastes, dredged materials, polluted sediments) by sequential extraction, International Conference "Heavy Metals in the Environment", Amsterdam, (1981) 698-704.

[14] P. Polić, P. Pfendt, Alluvial aquifer contamination: Carbonates and easily reducible oxyhydroxides as heavy metal substrates. Journal of the Serbian Chemical Society, 61 (11) (1996) 1001-1013.

[15] P. Polić, P. Pfendt, Iron and manganese oxides as dominant nickel substrates in the Novi Beograd aquifer, Journal of the Serbian Chemical Society, 57 (10) (1992) 697-703.

[16] W. Stumm, J. J. Morgan, Aquatic Chemistry - Chemical Equilibria and Rates in Natural Waters, 3rd ed., Environ.
Sci. Technol., A Wiley-Interscience Publication, 1996, p. 305.

[17] B. C. Han, W. L. Jeing, T. S. Hung, M. Y. Wen Relationship between copper speciation in sediments and bioaccumulation by matine bivalves of Taiwan. Environmental Pollution, 91 (1996) 33-35.

[18] P. Adamo, S. Dudka, M. J. Wilson, W. J. McHardy, Chemical and mineralogical forms of $\mathrm{Cu}$ and $\mathrm{Ni}$ in contaminated soils from the Sudbury mining and smelting region, Canada. Envir. Pollut., 91 (1996) 11-19.

[19] Z. Todorović, Potencijal akumulacije i mobilizacija teških metala iz sedimenata jezera "Barje" (Leskovac), Thesis, Deptartment of Industrial Chemistry, Faculty of Chemistry, University of Belgrade, 2003.

[20] J. Lopez-Sanchez, R. Rubio, G. Rauret, Comparison of two sequential extraction procedures for trace metal partitioning in sediments, International Journal of Environmental Analytical Chemistry, 51 (1993) 113-121.

[21] L. Ramos, M. J. Gonzalez, L. M. Hernandez, Sequential Extraction of Copper, Lead, Cadmium, and Zinc in Sediments from Ebro River (Spain): Relationship with Levels Detected in Earthworms, Bulletin of Environmental Contamination and Toxicology, 62 (1999) 301-308.

[22] J. E. Maskall, I. Thornton, Chemical partitioning of heavy metals in soils, clays and rocks at historical lead smelting sites, Water, Air, and Soil Pollution, 108 (1998) 391-409.

[23] M. Al-Awadi, W. J. Clark, W. R. Moore, M. Herron, T. Zhang, W. Zhao, N. Hurley, Dj. Kho, B. Montaron, F. Sadooni, Magnesium contents could originate, Oil field Review, 213 (2009) 32-45.

Izvod

\section{PROCENA SADRŽAJA I RASPODELE TEŠKIH METALA U POVRŠINSKOM SEDIMENTU AKUMULACIJE "BARJE" (SRBIJA)}

Zoran B. Todorović1 ${ }^{\text {, Ljiljana M. Ranđelović }}{ }^{\text {, Jelena Z. Marjanović }}{ }^{\text {, }}$

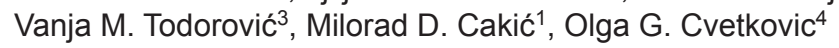

\footnotetext{
${ }^{1}$ Tehnološki fakultet, Univerzitet u Nišu, Leskovac, Srbija

2 Vodovod, Leskovac, Srbija

${ }^{3}$ Farmaceutski fakultet, Univerzitet u Beogradu, Beograd,Srbija

${ }^{4}$ Institut za hemiju, tehnologiju i metalurgiju (IHTM), Beograd, Srbija

Cilj ovog rada je da se ispitivanjem prirode asocijacija teških metala ( $\mathrm{Fe}, \mathrm{Co}, \mathrm{Ni}$, $\mathrm{Cu}, \mathrm{Cd}, \mathrm{Pb}, \mathrm{Mn}, \mathrm{Zn}$ ) izvrši identifikacija njihovih supstrata u akumulaciji "Barje" (Leskovac, Srbija), kao i da se definišu spoljni faktori (hidrološki i antropogeni koji utiču na njihovu raspodelu) što će doprineti boljem razumevanju interakcija koje se odigravaju u akumulaciji i prognozu mobilnosti na osnovu toga. Hemijska raspodela teških metala ispitana je korišćenjem metode sekvencijalne ekstrakcije i obradom dobijenih podataka statističkim metodama kao što su korelaciona, klaster i faktorska analiza. Na osnovu dobijenih rezultata može se zaključiti da se većina teških metala nalazi u rezidualnoj nepokretnoj frakciji (Fe, Zn i Ni). Zato što je u akumulaciji mali sadržaj organske supstance oksidi gvožđa i mangana su najznačajniji supstrati za vezivanje teških metala. lako je utvrđeno da je olovo i kadmijum karbonatne prirode njihove koncentracije u akumulaciji su zanemarljivo male.
}

(ORIGINALNI NAUČNI RAD) UDC 546.798:627.81

Ključne reči: teški metali, sediment, korelaciona analiza, faktorska analiza, akumulacija. 